University of California, Hastings College of the Law UC Hastings Scholarship Repository

Faculty Scholarship

2006

\title{
Creating Peer Sexual Harassment Mobilizing Schools to Throw the Book at Themselves
}

Jodi L. Short

UC Hastings College of the Law, shortj@uchastings.edu

Follow this and additional works at: http://repository.uchastings.edu/faculty_scholarship

\section{Recommended Citation}

Jodi L. Short, Creating Peer Sexual Harassment Mobilizing Schools to Throw the Book at Themselves, 28 Law \& Policy 31 (2006).

Available at: http://repository.uchastings.edu/faculty_scholarship/1193

This Article is brought to you for free and open access by UC Hastings Scholarship Repository. It has been accepted for inclusion in Faculty Scholarship

by an authorized administrator of UC Hastings Scholarship Repository. For more information, please contact marcusc@uchastings.edu. 


\title{
Creating Peer Sexual Harassment: Mobilizing Schools to Throw the Book at Themselves
}

\author{
JODI L. SHORT
}

\begin{abstract}
This paper describes how peer-to-peer sexual harassment rapidly was transformed from an unremarkable reality of secondary school life into a serious social and legal problem. First, it shows how organizations and professionals served as an entry point for social change and legal mobilization. I argue that schools were quick to address peer sexual harassment because activists framed it as a moral and pedagogical issue that resonated with educators' deeply held professional values. Second, the paper shows how law and organizations developed endogenously. Without any legal mandate, schools created and institutionalized harassment policies. Courts then looked to these organizational practices to determine the content and scope of Title IX. In this way, schools literally "enacted" the law through their practices. This finding goes beyond previous work on endogeneity in that school policies influenced law at the level of doctrine, not simply at the level of meaning, enforcement, or application.
\end{abstract}

\section{INTRODUCTION}

What happened to Johna Mennone in her environmental science class in the fall of 1990 left her feeling "humiliated, terrorized, and distraught." In the presence of her teacher and a roomful of classmates, Ms. Mennone says, a male peer grabbed her hair, legs, breasts, and buttocks nearly every day. ... In the past, what happened to Ms. Mennone might well have been chalked up to "high school" behavior of "boys being boys." Today, it is the subject of a federal lawsuit filed by Ms. Monnone against the district superintendent, the school board, and her teacher at Amity Regional High School in Woodbridge, Conn. Like Ms. Mennone, students across the nation-together with their parents, teachers and school officials-are beginning to deal with the thorny issues of how to define, prevent and punish sexual harassment among students. (Lawton 1993: §1)

Insightful comments by Lauren B. Edelman, Neil Fligstein and Kristin Luker are gratefully acknowledged. The author also would like to acknowledge all interviewees for the time and insight they provided, with special thanks to Nan Stein for her generous participation as well as her support and enthusiasm for the project.

Address correspondence to Jodi L. Short, University of California, Berkeley, Department of Sociology, 410 Barrows Hall, Berkeley, CA 94720-1980, USA. Telephone: 510-594-7467; E-mail: jodishort@earthlink.net. 
Beginning in the early 1990 s, educators came to see widespread and heretofore unremarkable student behaviors such as sexualized taunting and unwanted flirting as "peer sexual harassment," a social, pedagogical, and legal problem in need of a policy solution. As schools struggled to define and address peer sexual harassment at the level of organizational policy, federal courts were only beginning to wrestle with its legal implications. While courts took the better part of a decade to sort out who had what legal rights, schools took the lead in establishing and institutionalizing quasi-legal remedies for sexual harassment in the form of policies and grievance procedures. The institutionalization of these policy changes proceeded extremely quickly compared to such change in other areas; moreover, it proceeded without a clear threat of liability. This combination of circumstances provides a valuable window on the processes that produce change in both organizations and law.

\section{THEORETICAL BACKGROUND}

This article seeks to map the process by which schools and the constellation of professionals and organizations connected with them shaped both policy and law on peer sexual harassment. Theoretically, it is about how both formal law and "law in action" emerged from the same set of social processes. In this way, like much law and society scholarship, it responds to traditional legal scholarship that assumes law flows in uncomplicated fashion from the directives of formal legal institutions. In addition, however, it attempts to push further the law and society paradigm that focuses on "law in action" as an emergent feature of social life distinct from "law on the books." This literature too often ignores formal law altogether or assumes that it is the product of distinct processes that are cabined in formal legal institutions and somehow divorced from the social world in which "law in action" is rooted. This article is among many recent attempts to close this gap and to locate both formal law and "law in action" in the same set of social processes (Edelman, Uggen \& Erlanger 1999; Ewick \& Silbey 1998; Garth \& Sarat 1998).

Recent law and society scholarship has explored a variety of different approaches to closing the gap that has existed between "law on the books" and "law in action." One family of approaches advocates a "cultural turn" in legal studies. Sarat and Simon (2003: 14), for instance, theorize culture as a realm where the symbolic and the material are intrinsically connected and constitutive of one another. This approach privileges neither legal doctrine, as in traditional legal scholarship, nor "the social," as in much law and society scholarship, but analyzes both on the same footing as "forms of knowledge and power" that constantly produce and influence one another (Sarat \& Simon 2003: 6). Ewick and Silbey (1998), approach cultural analysis through the lens of "legal consciousness," a concept that attempts to capture the ways in which individuals create the meaning of law and legality in their everyday practices. This approach steps away from the "gap" by analyzing 
legality as "an emergent feature of social relations rather than an external apparatus acting upon social life" (Ewick \& Silbey 1998: 17). Still, even though their concept of legality encompasses formal law as a theoretical matter, legal consciousness analyses rarely attend to the way this very important aspect of legality emerges from social interactions. My analysis, by contrast, examines not only the meaning-making discourses and practices of schools, activists, and education professionals, but the way these both shape and are shaped by formal law.

Coming at the "gap" problem from a different angle, Edelman, Uggen, and Erlanger (1999), propose the concept of "endogeneity" as a way of capturing the reciprocal relationship between legal doctrine and the practices of regulated organizations: "That organizations are both responding to and constructing the law that regulates them renders law 'endogenous'; the content and meaning of law is determined within the social field that it is designed to regulate" (Edelman, Uggen \& Erlanger 1999: 407). They show how law and corporate policy developed endogenously in the Equal Employment Opportunity (EEO) context, describing how organizations adopted prophylactic anti-discrimination policies and grievance procedures on the advice of professionals such as lawyers, consultants, and human resources specialists; tracing how these gestures spread through professional networks across a broader and broader array of employers, supported by "rational myths" about their legal and economic value; and finally demonstrating how they began to yield tangible economic benefits to adopters as courts held them to be an appropriate response to EEO law.

Many scholars have documented similar institutionalization patterns (see, for example, Edelman 1992; Sutton et al. 1994). However, the bulk of this work focuses on the structural outcomes and determinants of institutionalization, largely ignoring or discounting the contribution of individual actors (DiMaggio 1988). This article builds on this literature by examining institutionalization as a political process, highlighting how meaning is actively constructed and contested on its way through the endogenous feedback loop. Edelman, Abraham, and Erlanger (1992) undertake a similar analysis, showing how legal and personnel professionals constructed the threat to employers of developments in the common law cause of action for wrongful discharge. In a legal environment presenting very little actual litigation risk to employers, they show how these professionals significantly inflated employers' risk both of being sued and of losing. They call this "process of extraction, interpretation, and dissemination," "the construction of law" (Edelman, Abraham \& Erlanger 1992: 48).

While this account illuminates the processes driving institutionalization, it confines itself to professionals aligned with the organizations they are advising. This article expands on these insights by highlighting the way actors normally considered outside the endogenous loop can intervene in the institutionalization process to mobilize it for political goals. Borrowing from literature on social movements, neo-institutional scholars have likened 
actors who engage in this kind of mobilization to entrepreneurs (DiMaggio 1988). Successful institutional entrepreneurs draw on the values and cultural commitments that animate organizations to frame issues and events in ways that resonate with the collective interests and understandings of organizational actors (McAdam, McCarthy \& Zald 1996). In this case, for instance, activist entrepreneurs were able to frame peer sexual harassment as an issue that threatened core educational values. This framing of the issue allowed it to be taken up, disseminated, and thus legitimated by networks of education professionals.

While this article is in many ways a story about the success of peer sexual harassment entrepreneurs in mobilizing the institutionalization process, it also suggests why social change achieved through this mechanism warrants skepticism and further study. Although organizations may accede to demands for regulation through the iterative endogenous process, their values, commitments, and interests will shape the substance and application of that regulation at every turn. Edelman, Erlanger, and Lande (1993), for instance, show how as firms increasingly legalize their handling of EEO complaints by adopting internal dispute resolution procedures, they simultaneously insert more and more of their managerial prerogatives into the interpretation of anti-discrimination law. Similarly, Edelman, Fuller, and Mara-Drita (2001) argue that it is management's embrace of EEO law-not its rejection-that has ultimately blunted anti-discrimination efforts in the workplace, as the filter of managerial rhetoric transforms civil rights law from a mandate for social justice to a voluntary quest for the softer goal of "diversity."

The seeming disjunction of law and organizational policy implementation is commonly understood as "decoupling," in Meyer and Rowan's (1983) terms, but this conception has serious limitations. In its focus on the tension between law and organizational goals, it fails to account for the ease with which each is able to assimilate the imperatives of the other. Endogeneity, on the other hand, explicitly attends to the cross-fertilization between legal and organizational/economic prerogatives and provides the tools to elaborate the relationship between the two. Thus, while it is beyond the scope of this article to assess whether the proliferation of sexual harassment policies has made any tangible difference in students' experiences of gender discrimination, I hope to suggest both the possibilities and the limitations of grounding legal change in organizational interests and goals.

\section{METHODOLOGY}

This article uses data derived from a variety of sources and methodologies, including: (1) legal analysis of the development of federal law under Title IX, up to and including the U.S. Supreme Court decision in Davis v Monroe County Board of Education (1999), which held schools liable for peer sexual harassment; (2) data establishing large-scale trends in the adoption of policies, 
including two nationwide surveys on peer sexual harassment, supplemented by school district policy manuals and interview data from school officials; (3) interviews with activists and education professionals to learn how they mobilized the cultural resources available to them to shape the organizational response to peer sexual harassment; and (4) analysis of education trade publications to track the dissemination of professional rhetoric on peer sexual harassment and its influence on policy and law.

\section{A. LEGAL ANALYSIS}

My legal analysis focuses exclusively on federal law under Title IX, because state law played no significant role in the legal development of school liability for peer sexual harassment. ${ }^{1}$

\section{B. INSTITUTIONALIZATION DATA}

I have two main sources of data for my argument that peer sexual harassment policies were highly institutionalized in schools prior to the Supreme Court's decision in Davis: (1) the Hostile Hallways survey; and (2) school district policy manuals. I note at the outset that my objective in presenting these data is not to establish precise patterns and levels of institutionalization, as has been done ably in other contexts (Dobbin \& Sutton 1998; Edelman 1992). Instead, my purpose in presenting them is to establish that there was a high degree of institutionalization around this issue and that it largely preceded the fixing of legal liability. From there, my focus shifts to the process that produced the high level of consensus.

To establish institutionalization, I use data from the Hostile Hallways surveys, commissioned by the American Association of University Women (AAUW) and conducted by Harris Interactive. ${ }^{2}$ These surveys provide the most comprehensive national data available on peer sexual harassment, and they are widely cited by everyone from researchers to federal court judges as illustrating the "state of the issue" on this topic. I have also compiled a sample of 222 school district policy manuals from districts in Arizona, Georgia, and South Carolina. These represent all policy manuals available online through state school boards associations that contain information regarding when individual provisions were adopted and/or revised. ${ }^{3}$ The sample contains 159 policies from Arizona, 42 policies from Georgia, and 21 policies from South Carolina. While the sample is dictated by availability, these three states represent a good cross-section of legal environments, and therefore are suggestive of broader trends. ${ }^{4}$

\section{INTERVIEWS}

I supplement the survey and policy data with targeted interviews for two purposes: (1) to confirm and elaborate on the picture emerging from the 
surveys about what is occurring in schools; and (2) to obtain information from key players in the legal and policy development process that would be otherwise unavailable from published sources. I interviewed two lawyers for Education Management Services (not the organization's real name), a forprofit company operating more than one hundred public schools in twenty different states across the country. I selected this organization because of its unique ability to provide a snapshot of trends across a broad swath of the country. In addition, I conducted interviews of a more investigatory nature with key players in the litigation and policy-making process surrounding peer sexual harassment to obtain information not available in documentary evidence. $^{s}$

\section{EDUCATION TRADE PRESS}

Other institutional studies have looked to professional journals as "a primary source of the diffusion of ideas" (Edelman, Abraham \& Erlanger 1992: 61). Accordingly, the crux of my empirical analysis is based on data from four leading education trade press publications: Education Week, Teacher Magazine, American School Board Journal, and The Bulletin of the National Association of Secondary School Principals. I selected these publications because they are widely circulated, and they reach those key groups of professionals most responsible for making policy in schools. Education Week is the most widely circulated magazine among educators, with a weekly readership of 218,000 education professionals. Teacher Magazine, American School Board Journal $(A S B J)$, and The Bulletin are the leading publications for teachers, school board members, and secondary school principals, respectively. ${ }^{6}$

My sample includes all articles from 1981-2001 that mention peer sexual harassment. ${ }^{7}$ I begin my search in 1981, one year after the Equal Opportunity Employment Commission declared "hostile environment" sexual harassment illegal in the workplace, to catch any early spillover effect EEO law might have had in schools, and I extend my sample range two years beyond the 1999 Davis decision to pick up lingering ripple effects from that case. In this twodecade span, there are forty-nine articles in these four publications, all concentrated between 1991 and 2000: thirty-seven in Education Week, three in Teacher Magazine, eight in ASBJ, and one in The Bulletin. ${ }^{8}$ I code these articles for eleven variables that capture key issues regarding the spread of information on peer sexual harassment, including their positions on liability and the evidence they use to support their arguments. A comprehensive coding key is at Appendix A.

\section{CREATING PEER SEXUAL HARASSMENT}

Schools developed and institutionalized policy on peer sexual harassment at a rapid pace and over a relatively short period of time. They did so not in 
response to a legal mandate like Brown $v$ Board of Education, which ordered desegregation of schools, or the Civil Rights Act (1964), which (among other things) ordered employers to stop discrimination in the workplace. They did so largely on their own initiative and in response to their own perceived institutional needs and values. To be sure, these changes occurred against a backdrop of litigation risk, but that risk was constructed and leveraged by feminist researchers, policy organizations, and educational professionals to create a consensus within the education community about the nature of the problem and the necessary solution, even as courts continued to argue over whether schools could even be held liable for the sexual harassment of students by other students.

The remainder of this article will trace how law and policy on peer sexual harassment developed endogenously. In Part A, I argue that the legal landscape facing schools on peer sexual harassment was confused and conflicting, and that it alone did not compel the actions of school officials. In Part B, I contrast the legal ambiguity with the clear and targeted response schools made to the issue. Part $C$ will explain how the intersection of particular actors, professionals, strategies, interests, and alliances constructed schools' response to peer sexual harassment and institutionalized the concept at the organizational level. I will argue that this institutionalization project was successful largely because institutional entrepreneurs were able to frame the issue in a way that resonated with the core value commitments of education professionals, and because the workplace and broader school law environment provided a ready store of pre-existing concepts and cultural models that made the issue quickly comprehensible to schools. Lastly, Part D will demonstrate how the process and the fact of institutionalization ultimately shaped legal doctrine on peer sexual harassment.

\section{A. THE LEGAL ENVIRONMENT}

It would be difficult to explain schools' broad adoption of peer sexual harassment policies strictly as a rational response to a legal mandate. Peer sexual harassment in schools was not recognized nationwide as a valid legal claim until 1999, when the U.S. Supreme Court decided Davis v Monroe County Board of Education. Before then, the law on this issue was conflicting and hotly contested. Title IX (1972), the portion of the Civil Rights Act addressing gender discrimination in education, provides: "no person in the United States shall, on the basis of sex, be excluded from participation in, be denied the benefits of, or be subjected to discrimination under any education program or activity receiving Federal financial assistance." The purpose of Title IX is to protect individuals from sex discrimination by denying federal financial aid to schools that discriminate on the basis of sex. Like many broad and vague legal provisions, Title IX is silent about what constitutes discrimination, what schools must do to prevent it, and what remedies are available if it occurs. 
Although there are some important differences in their language and structure, courts have long interpreted Title IX to impose similar requirements to Title VII (1964), the provision of the Civil Rights Act prohibiting employment discrimination (Oona v McCaffrey 1998; Kinman v Omaha Pub. Sch. Dist. 1996; Franklin v Gwinnett County Public Schools 1992). The law on sexual harassment in the workplace developed long before the law on sexual harassment in schools. As early as 1980, the Equal Employment Opportunity Commission (EEOC), the agency charged with enforcing the Civil Rights Act (1964), promulgated guidelines prohibiting "hostile environment" sexual harassment, or conduct that "has the purpose or effect of unreasonably interfering with an individual's work performance or creating an intimidating, hostile, or offensive working environment" (CFR 2002). ${ }^{9}$ Under the agency's interpretation, this included conduct by fellow employees even if they were not in a supervisory position. The U.S. Supreme Court validated the "hostile work environment" theory of liability in Meritor Savings Bank, FSB v Vinson et al. (1986) and Harris v Forklift Systems (1993), and subsequent circuit court decisions have uniformly interpreted these cases to hold employers liable for the harassing behavior of non-supervisory fellow employees if they know about it and do not make a reasonable effort to stop or prevent it (see, for example, Perry v Ethan Allen, Inc. 1997, Fleming $v$ Boeing Co. 1997).

In 1992, the U.S. Supreme Court considered for the first time how workplace rules on sexual harassment might apply in the school setting. In Franklin v Gwinnett County Public Schools (1992), the Supreme Court found that a girl who had been sexually harassed and assaulted by her coach could sue the school for damages under Title IX. Franklin was a watershed case in that it marked the first time the Supreme Court allowed a private party to sue a school district for monetary damages. It also signaled the high court's willingness to apply rules developed in the workplace context to schools. Nevertheless, Franklin was not so easily analogized to the issue of peer sexual harassment. The ruling concerned serious sexual abuse of a minor by an adult school employee. Consequently, many courts considered it irrelevant to what they saw as the very different issue raised by peer harassment.

While liability for peer sexual harassment in schools might have seemed the next logical step, three pervasive layers of reasoning made the workplace analogy problematic: (1) differences in the structure of the statutes; (2) federalism concerns; and (3) perceptions about the differences between child and adult sexuality. First, unlike Title VII, Title IX is a federal funding condition enacted pursuant to Congress's spending power. Rather than creating a general mandate to which all employers must adhere, it "makes funds available to a recipient [school] in return for the recipient's adherence to the conditions of the grant" (Rowinsky v Bryan Indep. School Dist. 1996 at 957). Statutes of this nature are generally construed narrowly, because they are seen as a "contract" between the government and the funding recipient that cannot fairly impose requirements the recipient could not have 
expected when it accepted the grant (Davis v Monroe County Board of Education 1997 at 1399). Based on this reasoning, two courts of appeal held that peer sexual harassment was precisely the kind of unforeseeable exigency that should fall outside the reach of a funding statute (Davis v Monroe County Board of Education 1997; Rowinsky v Bryan Indep. School Dist. 1996), and the Supreme Court dissenters also would have rejected the Title IX claim on this basis (Davis v Monroe County Board of Education 1999 at 657).

In addition, the Davis case arose in the broader context of the U.S. Supreme Court's crusade to resurrect long dormant doctrines of federalism that limit Congressional law-making power in deference to state and local government policies (see, for example, United States $v$ Lopez 1995). Since the New Deal, Congress's power to legislate under the commerce clause had been taken for granted and virtually uncontested, but after Lopez, legislation that arguably impinged on state and local prerogatives had to be viewed through the lens of the slim new majority's anxiety about the exercise of federal power. Peer sexual harassment presented significant federalism concerns, touching not only on the sensitive topic of sexuality but on the quintessentially local character of schools. While federalism arguments rarely appeared in lower court decisions, they formed the basis of a strenuous dissent in the Supreme Court:

In the final analysis, this case is about federalism.... Preserving our federal system is a legitimate end in itself. It is, too, the means to other ends. It ensures that essential choices can be made by a government more proximate to the people than the vast apparatus of federal power. Defining the appropriate role of schools in teaching and supervising children who are beginning to explore their own sexuality and learning how to express it to others is one of the most complex and sensitive issues our schools face. Such decisions are best made by parents and by the teachers and school administrators who can counsel with them. (Davis v Monroe County Board of Education 1999 at 684-85)

Doctrinal issues aside, the taboo of child sexual behavior confounded what in another context might have been a relatively straightforward legal issue. Language from a number of federal courts of appeal, as well as from the Supreme Court dissenters, reflects deep anxiety about drawing analogies between adult and adolescent sexuality:

Sixth grade students experience that mysterious in-between time of life where they are too old for Barbie dolls and toy soldiers, but too young for high heels and drivers' licenses. Even adults are unsure how to interpret pre-teen behavior. (Bruneau v South Kortright Central Sch. Dist. 1998 at 752)

[Eliminating peer sexual harassment] would be an impossible task, for schools are full of all sorts of kids, and every school has its share of buffoons, yokels, and dunderheads of all stripes. And unlike harassers in the work place, students can't be fired. Schools are also full of kids with raging hormones who may be crude and insensitive when dealing with students of the opposite sex. (Doe $v$ University of Illinois 1998 at 78)

Unlike adults in the workplace, juveniles have limited life experiences or familial influences upon which to establish an understanding of appropriate behavior. 
The real world of school discipline is a rough-and-tumble place where students practice newly learned vulgarities, erupt with anger, tease and embarrass each other, share offensive notes, flirt, push and shove in the halls, grab and offend. ... It is doubtless the case, moreover, that much of this inappropriate behavior is directed toward members of the opposite sex, as children in the throes of adolescence struggle to express their emerging sexual identities. It is a far different question, however, whether it is either proper or useful to label this immature, childish behavior gender discrimination. (Davis $v$ Monroe County Board of Education 1999 at 672-73, quoting National School Boards Association Brief at $10-11)$

Thus, despite the line of case law analogizing Title VII and Title IX (Oona v McCaffrey 1998, Kinman v Omaha Pub. Sch. Dist. 1996, Franklin v Gwinnett County Public Schools 1992), many judges were convinced that peer sexual harassment in the schools presented an entirely different issue than peer sexual harassment in the workplace. As the Davis dissenters put it: "schools are not workplaces and children are not adults" (Davis v Monroe County Board of Education 1999 at 675).

As a result, although many have argued that the analogy to Title VII hostile environment law was clear, getting courts to recognize this right under Title IX was a difficult and uncertain proposition. The first published case on peer sexual harassment, Doe $v$ Petaluma City School District (1993), held that Title IX permits victims of peer sexual harassment to sue for damages. Before Doe, no plaintiff had tried to hold a school liable for damages under Title IX based on a sexually hostile environment created by the acts of other students. The next peer sexual harassment case in the pipeline, published in 1994, explicitly rejected the Doe court's analysis, ruling that the school district could not be held liable for peer sexual harassment because "[t]he sexually harassing behavior of a fellow fifth grader is not part of a school program or activity" and no school district employees had played a role in the harassment (Davis v Monroe County Board of Education 1994 at 367). Following these two cases and leading up to the Supreme Court's consideration of the issue, twenty-four other district courts, as well as six courts of appeal, divided on whether peer sexual harassment was actionable under Title IX. As the Second Circuit Court of Appeals described the landscape in 1998:

The law does not clearly impose a duty on school officials under Title IX or the Fourteenth Amendment to stop peer sexual harassment. Indeed, there are no court of appeals cases before 1998 holding school officials potentially liable for peer sexual harassment in the school environment. Even now, there is disagreement among the circuits as to whether a school district and school officials may be held liable for sexual harassment where the officials are not directly involved in the harassment. (Bruneau v South Kortright Central Sch. Dist. 1998 at 755 , emphasis added)

The law was no clearer one year later when the Supreme Court took up the issue: four of the eleven circuits held schools liable on some basis for peer sexual harassment; two other circuits found no liability for peer sexual 
harassment; and law in the district courts remained a confusing and conflicting patchwork.

On 24 May 1999, a sharply divided U.S. Supreme Court decided Davis $\checkmark$ Monroe County Board of Education (1999). Over the strident dissent of four justices, the majority held that:

\begin{abstract}
a private damages action may lie against the school board in cases of studenton-student harassment, ... but only where the funding recipient acts with deliberate indifference to known acts of harassment in its programs or activities. Moreover, we conclude that such an action will lie only for harassment that is so severe, pervasive, and objectively offensive that it effectively bars the victim's access to an educational opportunity or benefit. (Davis v Monroe County Board of Education 1999 at 632)
\end{abstract}

Departing from standard court decorum and employing a tactic reserved for displays of deep displeasure with the majority decision, Justice Kennedy read parts of his dissent aloud from the bench. Lamenting that, "[a]fter today, Johnny will find that the routine problems of adolescence are to be resolved by invoking a federal right to demand assignment to a desk two rows away" (Davis v Monroe County Board of Education 1999 at 686), Justice Kennedy condemned the imposition of liability on school districts that could not possibly have seen it coming and warned ominously that they would be crushed by the financial burden of litigation.

\title{
B. THE ORGANIZATIONAL RESPONSE
}

The picture that emerges on the organizational landscape, however, belies the dissent's strenuous concern. Schools not only anticipated that they could be liable for peer sexual harassment, but by the time the Supreme Court got around to deciding the issue, they had already institutionalized a quasi-legal policy apparatus to address it. In 1993, the year the first federal district court case addressing peer sexual harassment was published, 26 percent of students surveyed for Hostile Hallways reported that their school had a sexual harassment policy in place. By 2000, 69 percent of students said their school had such a policy. ${ }^{10}$ Available data on actual school policies also suggest widespread institutionalization. Of 222 policies available online for school districts in Georgia, Arizona, and South Carolina, 57 percent contained a provision explicitly addressing peer sexual harassment by 2000 . That number jumps to 77 percent by 2001; 92 percent by 2002; and 97 percent by 2003 . Perhaps even more telling than the overwhelming percentage of school districts that adopted peer sexual harassment policies so quickly after Davis is the proportion that had them in place before. Overall, 40 percent of these school districts had adopted a policy on peer sexual harassment before the Supreme Court decided they could be liable for it. My interviews with officials at Education Management Services (EMS) also support this trend. EMS manages more than one hundred public schools in twenty different states. It reports that virtually all of these schools had their own 
peer sexual harassment policies in place at the time EMS took over, throughout the mid-1990s. By 1999, the same year the Supreme Court decided Davis, EMS required all of its schools to have a policy on peer sexual harassment.

The adoption rate of school sexual harassment policies is extremely rapid in comparison with the institutionalization of other kinds of organizational policies, and is notable in that much of it preceded any legal mandate. In Edelman's (1992) classic study tracking adoption of policies proscribing workplace discrimination, it took employers fifteen years from the enactment of the Civil Rights Act (1964) to reach an adoption threshold of 69 percent. Schools reached a threshold of that magnitude in just one to two years after the U.S. Supreme Court mandated a remedy for peer sexual harassment. This suggests that institutionalization was underway long before liability was legally established.

\section{INSTITUTIONAL MOBILIZATION}

\section{The Institutional Entrepreneur}

In many ways, peer sexual harassment as a category, a concept, and an issue grew out of the empirical work of a handful of feminist researchers. It is hard to do any research at all on peer sexual harassment without running across Nan Stein. Stein has conducted extensive research on peer sexual harassment, published four books and more than twenty articles on the subject, created handbooks and curricula for educators and policymakers, debated the issue on television and radio talk shows, served as a consultant for numerous school districts, and been retained as an expert witness in peer harassment litigation. Stein constructed and disseminated the narratives about peer harassment that were taken up by the media, schools, and eventually courts.

While working at the Massachusetts Department of Education in the late 1970 s, Stein heard about antics among the department's student interns that raised her interest and concern:

I said, "gee this sounds like sexual harassment at work except there is no boss in there to hire and fire, there is no teacher there who can give him a better grade. So what we have going on here is a student-to-student thing." And then I wanted to find out how typical was this, was this just some anomaly or was this how they experienced it at school? ${ }^{11}$

Stein conducted exploratory research in the late 1970 s and found that sexually harassing behavior was rampant among fellow students, and that teenage girls bore the brunt of it. Under a federal grant to the Massachusetts Department of Education, Stein studied the issue in greater depth through the creation of a "sexual harassment task force," a committee she coordinated, which included several colleagues at the Massachusetts DOE, along with 
concerned Massachusetts educators. The project culminated in a curriculum drafted by Freada Klein and Nancy Wilbur for the Massachusetts DOE called Who's Hurt and Who's Liable: Sexual Harassment in Massachusetts Schools: A Curriculum and Guide for School Personnel. The first edition of Who's Hurt and Who's Liable was published in 1979, one year before the EEOC proscribed worker-on-worker sexual harassment on the job.

Stein admits that she and her colleagues were in the vanguard. No one else was really looking at peer sexual harassment in schools at that time. She also admits that they were way out in front of the law on this issue.

[W]e didn't have any way to claim legally that this applied to schools. ... We came up with that title [Who's Hurt and Who's Liable] because we wanted superintendents to sit up and take notice.... [W] all knew that there were no lawsuits to back this up. ${ }^{12}$

Unphased by the lag in the law, Stein focused her efforts directly on school organizations. Long before peer sexual harassment reached the courts as a legal issue, Stein used her empirical research to define it at the organizational level as a moral and pedagogical issue: "[W]e were making progress on this even before ... any of the liberal circuits ruled that students were liable for student-to-student harassment. Way before." While she waited for the law to catch up, she continued to document cases of harassment, interview girls about their experiences and disseminate her findings among education professionals. "So I kept ... gathering data ... from kids, and I would use that to kind of legitimate this issue even though I didn't have lawsuits to back me up."

Stein widely disseminated her findings throughout the educational community, conducting training workshops for state education departments and Title IX coordinators, speaking at statewide conferences for guidance counselors and social studies teachers, publishing books and manuals on the issue for educators, and writing editorials for widely circulated education publications. In just a little over a decade, Stein and her initial shoestring research had created a great deal of interest on peer sexual harassment in the educational community as well as in the popular press. In September 1992, Seventeen, a magazine read by 2.1 million teen girls each month, published an article about sexual harassment in schools, accompanied by a survey encouraging readers to report their experiences. Over 4,200 girls ages nine to nineteen responded. Stein and her colleagues at the Wellesley College Centers for Women coordinated the research and published the results (Stein, Marshall \& Tropp 1993), and Seventeen reported the eye-catching findings in its May 1993 issue: 89 percent of girls reported experiencing some sort of sexual harassment at school; and 39 percent reported experiencing harassment on a daily basis. Although critics quibbled that the methodology produced a biased sample, the appearance of these startling numbers in a widely circulated, mainstream magazine put peer sexual harassment on the map. 
Shortly after the Seventeen study came out, the Association of American University Women (AAUW) published its own survey on sexual harassment. Hostile Hallways was the first peer sexual harassment study using a randomly selected national sample of teens of both genders. The findings were remarkably consistent with the Seventeen study: four out of five students reported that they had been the target of some form of sexual harassment during their school lives ( 85 percent of girls and 76 percent of boys); of those experiencing harassment, one in four report being harassed "often" (31 percent of girls compared with 18 percent of boys). The study found that while a small portion of those harassed had been targeted by an adult school employee, the vast majority were being harassed by their peers. These studies were widely covered in the popular press, with segments devoted to their findings appearing on The Today Show, NBC Nightly News, CNN, Nightline, CBS Evening News, The Oprah Winfrey Show, and Good Morning America.

\section{Construction and Dissemination Through Professional Networks}

As the mainstream media raised the public profile of the issue, the education trade press played a key role in disseminating this information among education professionals. On 27 November 1991, Education Week published the first article in a major education trade publication on peer sexual harassment. Authored by Stein, the piece described several specific incidents of peer sexual harassment, argued that the behavior was prevalent, and made recommendations about how schools could address it. The article also provided an exaggerated assessment of the state of the law on peer sexual harassment at that time:

[I]t is against the law and is a form of sex discrimination, a violation of the federal statutes Title IX and Title VII. It may also violate state criminal and civil statutes. And some forms of sexual harassment may be actionable as child abuse, sexual assault, rape, pornography, criminal or civil libel, slander, or defamation of character. Victims, as well as educators or community members acting on the victim's behalf, may file sexual-harassment complaints. (Stein 1991: 32)

As discussed above, the legal picture was hardly this clear. In fact, no published case on peer sexual harassment existed in 1991, when Stein made this claim. Instead of citing legal authority, Stein bolstered her claim by invoking two broader cultural phenomena: the fractious Hill-Thomas confirmation hearings and the as-yet-undecided Franklin case, involving the sexual abuse of a student by a teacher.

Analysis of a decade's worth of articles on peer sexual harassment in the education trade press reveals many similar elisions. These articles reinforced and legitimated peer sexual harassment as a legal construct by largely ignoring or downplaying the controversy in the courts that would ultimately decide the issue. They created a climate that begged a response, and in this way, they helped construct what the appropriate response would be. 
Between 1981 and 2001, forty-nine articles mentioning peer sexual harassment (all concentrated between 1991 and 2001) appeared in the education trade press, with a significant majority appearing in the widely circulated Education Week. Of the thirty-four articles that discuss liability prior to the Davis decision, twenty-five ( 74 percent) explicitly state that school districts can or should be held liable for the sexual harassment of students by other students, or describe a court case holding a school district liable. Significantly, it is the early articles-those appearing when the legal landscape was most unsettled - that most strongly suggest school liability for peer sexual harassment; this view becomes tempered or complicated only later. From 1993 through 1996, 87 percent of articles that discuss liability either state or suggest that schools are liable for students' sexual harassment of their peers. Moreover, of the six articles that either do not discuss liability or do not suggest that schools are liable for it, four nevertheless recommend that schools adopt a peer sexual harassment policy to deal with it. Notably, none of these articles attempt to provide a legal definition of peer sexual harassment, creating the uneasy sense that this is a problem of uncertain scope and magnitude. It is not until 1997 that the articles begin to paint a more complex picture of the liability landscape, highlighting suits won by school districts and reporting the law's ambiguity. Table 1, below, summarizes the trade press article data. ${ }^{13}$

In the absence of settled law on the issue, early articles cited a variety of evidence outside of actual court rulings to bolster the case for liability. For instance, two-thirds of the articles from 1991-92 included anecdotes about schools that had paid settlements to victims of peer sexual harassment, like the Minnesota district that "learned an expensive lesson about its failure to act to halt the alleged sexual harassment of a student by a peer" (Walsh 1991: 15). While silent on the state of peer sexual harassment law, these articles made salient the risk of liability for a claim that had never even been legally tested, much less established.

The Anita Hill-Clarence Thomas hearings were another common theme in the early articles, mentioned in six of the first eight articles to appear. This historical event provided Stein and other institutional entrepreneurs a "break" or a "reframing" of general understandings that changed perceptions of previously accepted behavior and opened up political opportunities for mobilization (Zald 1996).

Educators often cite the October 1991 allegations of sexual harassment against then-Supreme Court nominee Clarence Thomas by Anita Hill, a law professor, ... as helping to shape their thinking on harassment.... [B]efore the Thomas-Hill hearings, many school administrators were not willing to acknowledge that sexual harassment of any kind was a problem in their schools. (Lawton 1993: \$31-32)

The national debate on workplace harassment sparked by these hearings provided activists and education professionals with a widely accessible cultural script and with a political moment ripe for action and change on the issue. 


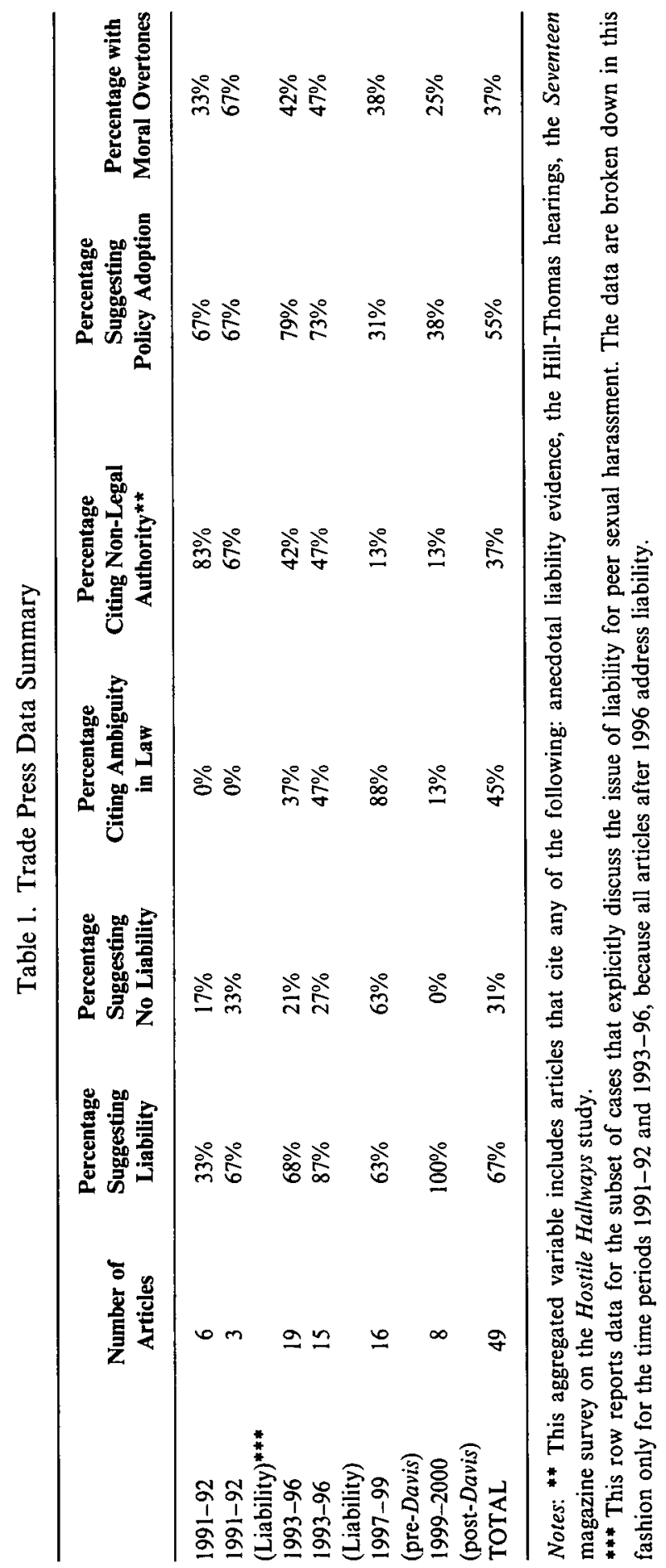


It is worth noting, however, that there is very little evidence in these publications that schools looked to developments in workplace sexual harassment law. Only nine of the forty-nine articles (18 percent) reference EEO law, and most of these mention it only in passing. It was not so much the law of workplace sexual harassment, but the popular framing of this issue through media events like the Hill-Thomas hearings that supplied activists with ready cultural templates to mobilize schools into action.

One legal development that trade publications did cover widely was Franklin $v$ Gwinett County School Board (1992), the Supreme Court case that found school districts could be liable in money damages for sexual harassment of students by teachers and school employees. This landmark case was mentioned in half of the first eight articles to appear, with many suggesting an analogy to peer sexual harassment.

The issue already had educators' attention by 1993 , when the Seventeen magazine and Hostile Hallways studies appeared, but this research triggered an explosion of coverage. The number of articles on peer sexual harassment appearing in 1993 alone (eight) exceeded the total number that had come before, and was exceeded only by 1999 (the year Davis was decided) for the highest yearly article total. This new research was a frequent topic of the 1993 articles, with half of them discussing one or both studies. It also precipitated a sharply moral turn in the debate on peer sexual harassment.

Their letters arrive by the hundreds daily, screaming to be read: "OPEN," "URGENT," and "PLEASE READ" are scribbled on the envelopes.... Inside the envelopes are chilling stories, handwritten on lined notebook paper or on perfumed stationary.... All beg for attention, for answers, and, above all, for some type of justice... This pernicious problem in our schools is a national disgrace. To thousands of adolescent girls, school may be teaching more about oppression than freedom; more about silence than autonomy. (Teachers Magazine 1993: $\$ 4-5,12$ )

Along with the heightened awareness that these studies brought to the issue came a heightened sense that schools must take some sort of action. Here too, the employment context provided a ready blueprint. For several decades since passage of the Civil Rights Act (1964), employers had struggled with how to implement its anti-discrimination mandates. The solution that most eventually adopted was quasi-legal internal policies and grievance procedures (Edelman 1992; Sutton et al. 1994). As courts recognized the validity of these procedures, they became an increasingly legitimate response to the legal demand of anti-discrimination (Edelman, Uggen \& Erlanger 1999). In a pair of 1998 rulings, the U.S. Supreme Court provided the ultimate validation, holding that employers could avoid sexual harassment liability altogether if, among other things, they had in place an effective, well-publicized antiharassment policy that the victim had failed to invoke (Faragher $v$ City of Boca Raton 1998; Burlington Industries $v$ Ellerth 1998). While the education trade press did not specifically identify the employment context as the source of this solution, it readily disseminated the workplace template by 
urging schools to adopt sexual harassment policies. As early as 1991, Education Week published an article suggesting, among other things, that schools adopt a clear policy for identifying and addressing peer sexual harassment cases (Stein 1991). Harassment policies remained an ongoing theme-more than three-quarters (76 percent) of all articles appearing from 1991 through 1996 suggested that schools should adopt a peer sexual harassment policy to deal with the growing problem.

But for many education trade reporters, peer sexual harassment was about much more than just law and policy. More than a third of the articles appearing prior to the Davis decision (39 percent), discussed peer sexual harassment as a moral issue implicating deeply held educational values. Benjamin Sendor, legal analyst for the American School Board Journal, wrote several polemics on the issue urging educators to take responsibility for peer sexual harassment as a moral and educational matter irrespective of their potential legal liability for it (Dowling-Sendor 1998; Sendor 1996a, 1996b). Sendor sharply criticized courts that failed to find liability for peer sexual harassment and urged schools to ignore them, arguing that "[w]hat's more important [than the law], we should all agree that inaction in the face of known sexual harassment is morally and educationally inexcusable" (Sendor 1996b: 19).

The moral rhetoric was even more strident in a number of books published during this same time period. Geared toward educators and policymakers, they combined anecdotes gathered from interviews of school age girls with overblown assessments of the state of the law and urgent moral entreaties (Larkin 1994; Layman 1994; Shoop and Hayhow 1994; Stein 1994). For instance, Shoop and Hayhow deliver this dire warning:

The costs and consequences of sexual harassment in our schools are extreme.

They are extreme in the devastation of our daughters. They are extreme in the dysfunctional and counter productive manner in which our sons are socialized to relate to their mothers, sisters, wives, female friends, and coworkers. They are extreme to our economy, to our ability to compete in the world marketplace, and even to the American standard of living. For these reasons eradicating sexual harassment in our schools is an urgent priority. (Shoop \& Hayhow 1994: preface)

They also caution against a misplaced reliance on the law to solve the problem:

While an understanding of the legal aspects of sexual harassment is important, we believe this is only part of the larger picture. Laws and punishment do little, if anything, to help us understand the underlying causes of the behavior. To an overwhelming degree, the law treats the symptoms and ignores the disease. That model seldom works in the medical community and it is similarly ineffective when applied to sexual harassment. (Shoop and Hayhow 1994: preface)

These authors sought to frame peer sexual harassment as a moral and pedagogical issue first and foremost, and a legal problem only secondarily.

These books also reveal the close connection and cross-fertilization among activists, researchers, educational professionals, and education policy 
organizations. Stein's book, for example, was published by the National Education Association, a prominent national policy organization. Moreover, many of these books were authored by educational consultants-professionals who played a key role in constructing the meaning of peer sexual harassment for the individual schools that employed them. Stein worked as a consultant helping schools to develop policy on peer sexual harassment. And Jack Hayhow is the founder and president of Video Training, Inc., whose library includes Sexual Harassment: What Is It and Why Should I Care? In addition to their political interests, these authors had a professional, material stake in the widening concern over peer sexual harassment that helped drive the issue.

The trade press and the paid consultants, however, were not alone in calling attention to peer sexual harassment, in representing it as a threat to important pedagogical values, and in recommending remedial measures. Around this same time frame in the early to mid-1990s, prominent national education policy organizations began to echo and reinforce the concerns and recommendations appearing in the trade press. The National School Boards Association (NSBA) addressed the issue on a variety of fronts. In addition to the stern polemics it published in American School Boards Journal, the organization drafted a model sexual harassment policy in 1993 and urged members to adopt it. The NSBA reported to Education Week that it had been sponsoring training programs on sexual harassment for school districts since the early 1990s (Walsh 1993). The National Education Association (NEA) released a sexual harassment training video in 1992 to help teachers recognize and respond to peer and other forms of sexual harassment. It stressed the importance of instituting a sound sexual harassment policy. In 1995, the National Middle School Association released its own peer sexual harassment videotape directed at middle school students.

Beginning in 1997, following this multi-layered barrage of anti-peer harassment messages, education trade publications started painting a much more complicated picture of liability for peer sexual harassment. A significantly greater percentage of articles from 1997 up to the Davis decision included either coverage of cases finding school districts had no liability to victims of peer sexual harassment or statements indicating that the law was conflicting and unsettled. Between 1991 and 1996, only 20 percent of the articles mentioned a case won by the school district, while 63 percent of articles published from 1997-99 (pre-Davis) described such a case. Moreover, these later articles were much more likely to acknowledge ambiguity in the law. Only 28 percent of the 1991-96 articles state that the law is unclear or present case law on both sides of the issue, but this number jumps to 88 percent of the articles in the two years leading up to Davis. Perhaps even more significantly, nine of the ten articles that suggest liability for schools during this time period admit that this position is not clear. As the Supreme Court's consideration of Davis approached, the education press painted an 
increasingly complicated picture of the law on peer harassment, admitting that liability was not clearly established. By this time, however, it appears that schools already had got the message.

\section{Resonance with Organizational Values}

Faced with this barrage - of data and anecdotes about the damage to students of peer sexual harassment, of inflated warnings about liability risk, and of moral entreaties-school districts embraced peer sexual harassment as their problem to solve. As described above, a large proportion of schools already had a policy on the books by the time Davis was decided. Moreover, my interview data confirm that schools were responding to something beyond simple calculation of liability risk, and that their responses were strongly influenced by the way activists and professionals had framed the issue. Asked to explain why her school district adopted a peer sexual harassment policy in 1994, a middle school administrator explained the decision in terms of general political trends and, specifically, the advice of trade organizationswithout mentioning the risk of litigation.

Sometimes policies come out of ... general trends in the United States. The Boards are associated with national organizations and as things become issues, then the Board is apt to write their own policy.... I think there was a general trend in public schools to look at the issue of sexual harassment as more than a situation of teasing.... [I]t was at a time when this was being given some national attention, the National Middle School Association put out this video tape, which we use quite regularly. ${ }^{14}$

Perhaps the best evidence that these organizational developments had their own independent trajectory is the institutional commitment of organizations to these policies regardless of liability. General Counsel for EMS reports that even if the Supreme Court had absolved schools of liability for peer sexual harassment, the company would not have changed or eliminated the policies already on the books: "I doubt frankly that any district out there would have. Even if the Supreme Court had said these aren't actionable, they wouldn't have changed their policies."15

Organizations often act based on their collective understanding of what the law should be rather than an accurate assessment of what the law is (Gould 2001), and schools had come to see peer sexual harassment as something for which they should take a certain measure of responsibility. Stein explains that peer sexual harassment "was one of those things that had the ring of truth to it, and nobody was denying it, so it almost didn't matter that there weren't lawsuits." ${ }^{\prime \prime}$ Just after the Supreme Court decided Davis, Education Week reported: "School administrators reacted with surprising acceptance to the U.S. Supreme Court's ruling last week that districts may be sued for damages if they fail to respond to student sexual harassment of other students" (Walsh 1999: 1). EMS General Counsel put it this way: 
[T]here are things that in essence, forgetting about how these policies are written, there are things that you're going to do anyway. I mean, for example, a young female student in one of your schools complains about unwanted sexual attention. I mean, you know, you're creating a learning environment for everybody. You have to respond on some level even if it wasn't actionable under the law. ${ }^{17}$

This was the "ring of truth" that motivated schools to act irrespective of the law.

\section{LEGAL MOBILIZATION}

This constellation of professional rhetoric and activity at the organizational level impacted not only the development of school policy, but also the development of formal law on peer sexual harassment. NOW Legal Defense and Education Fund (NOWLDF) served as either counsel or amicus in nearly every peer sexual harassment case litigated in the country. Their legal strategy cultivated developments at the organizational level and leveraged them to construct the case for legal liability under Title IX. While NOWLDF litigators felt confident that the legal doctrine was on their side, they recognized the difficulty they faced in articulating this issue for courts. Yolanda $\mathrm{Wu}$, lead litigator on peer sexual harassment for NOWLDF, explained:

I think we worried at times that ... courts weren't really ready to see this as a legal violation yet, and then in terms of ... the culture, the general public didn't understand it. I think at the beginning we had the sense that you couldn't just ... look at it in the courts, that the whole general public part of it was really critical. ${ }^{18}$

In order to make its legal case, NOWLDF marshaled the same kinds of arguments and evidence that had shaped the issue at the organizational level. NOWLDF co-sponsored research to document empirically the nature and prevalence of peer sexual harassment, including the Seventeen magazine study conducted by Nan Stein and her colleagues. Wu stressed the connection between empirical research and litigation strategy:

[It's really critical that you have the data to support whatever legal arguments you're going to make.... I think [social science research is] persuasive [to courts], especially from an anecdotal point of view. One of the most helpful things about the Seventeen survey was just sort of putting the girls' own words in front of the court. ${ }^{19}$

She also stressed the importance of disseminating this kind of information to schools. Like many of the activists and education policy organizations, NOWLDF sent speakers to secondary schools and education conferences, and disseminated its own set of educational materials and model policies on peer sexual harassment to students and schools. Gaining a foothold in organizational policy was a crucial piece of the NOWLDF litigation strategy. 
This multi-layered legal strategy coupled with the broad institutionalization of peer sexual harassment policies at the organizational level directly influenced the Supreme Court's legal analysis of Title IX. To be sure, these kinds of strategies are not novel among legal and policy activists. What is striking in this case is that the court explicitly recognized that the prohibition of peer harassment was in essence already the law at the organizational level. In her majority opinion, Justice Sandra Day O'Connor wrote:

At the time of the events in question here, in fact, school attorneys and administrators were being told that student-on-student harassment could trigger liability under Title IX. In March 1993, even as events alleged in petitioner's complaint were unfolding, the National School Boards Association issues a publication, for use by "school attorneys and administrators in understanding the law regarding sexual harassment of employees and students," which observed that districts could be liable under Title IX for their failure to respond to studenton-student harassment. ... [W] do find support for our reading of Title IX in the fact that school attorneys have rendered an analogous interpretation. (Davis v Monroe County Board of Education 1999: 647)

Surely the United States Supreme Court had no obligation to defer to the opinion of a private organization on an issue of statutory construction. The Court's reliance here on the institutional process that produced the law as it came to be understood in organizations suggests an awareness of its role in an endogenous feedback loop.

If the majority implicitly recognized the subtle interaction between organizations, institutions, and the law, the dissent missed it entirely. The dissent made dire predictions about the flood of lawsuits that would swamp the courts following Davis. To the contrary, however, there has been no flood of litigation since Davis - in fact, there is barely a trickle of cases now reaching the courts. ${ }^{20}$ Shortly after the case came down, Education Week reported: "What was most striking about the reaction to last week's ruling was that educators and school district lawyers, while expressing some dismay with the outcome, were not nearly as troubled as Justice Kennedy" (Walsh 1999: 22). As one frequent commentator succinctly put it in his article reporting the outcome of the Davis decision, "I told you so" (Dowling-Sendor 1999: 16).

\section{CONCLUSION}

I don't know how to describe what happens in court. People make law too, right? People invent law, they interpret law, they think law is at their disposal-I don't know-they think law is going to save them. ${ }^{21}$

This account reveals how the endogenous relationship between law and organizations produces both formal law and law in action from the same set of social, legal, political, cultural, and discursive processes. Here, the diffusion by activists of a small constellation of data, anecdotes, and incidents resonated 
with the professional commitments of educators and produced sweeping policy change that occurred largely independent of relevant changes in the law. These activists and their professional allies tapped into institutional mechanisms to mobilize change and action at the organizational level, and these organizational changes drove the development of legal doctrine. I do not mean to suggest that law played no role here. That this issue was articulated and pursued through the courts certainly influenced the direction it took within organizations (McCann 1994). However, it is clear that schools responded to something other than legal mandates or calculable liability risks as they created policy on this issue, and that courts looked to schools to interpret the law.

While this article has documented real and significant legal and organizational change, it remains to be seen whether legal liability, school policies, and grievance procedures can produce meaningful social change for students who are sexually harassed by their peers. The follow-up Hostile Hallways survey indicates that while awareness about the issue and school policy adoption have increased dramatically, students continue to report being sexually harassed by their peers at the same rate as in 1992 . While schools appeared eager to embrace reform, they did so by grounding the rationale for these reforms in neutral values such as fair treatment and the maintenance of a hospitable learning environment. Significantly, peer sexual harassment remedies were never justified by education professionals on legal or political grounds like justice, equality, or remedying discrimination, and this may limit their ability to meaningfully protect students whose legal rights are violated.

This article highlights the tight connections between law and policy development precisely because this relationship has significant consequences for the way organizations understand and implement their legal obligations. On the issue of peer sexual harassment, activists worked an astonishing legal and organizational transformation by grounding the construct in the shared cultural understandings of educators. However, these pre-existing understandings may ultimately limit what the construct can and will mean. It is for this reason that future research should continue to tease out the connections, and not simply the gap, between organizational practices and formal law.

JODI L. SHORT is a PhD candidate in sociology at the University of California, Berkeley, with a JD from Georgetown University Law School. Her research investigates the intersection of private regulatory mechanisms, state regulatory agencies, and the law.

\section{NOTES}

1. A comprehensive LEXIS search found no pre-Davis cases brought under state law seeking to hold a school district liable in damages for peer sexual harassment. Furthermore, a LEXIS search of state statutory and administrative codes 
found only two that addressed peer sexual harassment: an Indiana statute enacted after Davis and a 1993 California education statute requiring schools, among other things, to enact a sexual harassment policy, but which contains no private right of action to sue for its violation (Clausing $v$ San Francisco Unified School District 1990).

2. Harris conducted two nationwide surveys on sexual harassment in secondary schools for the AAUW: one in 1992 and one in 2000. In 1992, Harris surveyed over 1,600 public school students in eighth through eleventh grades. In the followup survey, Harris surveyed (by both questionnaire and interviews) a total of 1,559 public school students in eighth through eleventh grades, between 7 September and 22 November 2000 . I sought but was not permitted access to the raw data underlying these surveys. Consequently, any conclusions drawn here are based only on the published results of these surveys.

3. The Kentucky School Boards Association also maintains a database of online policies; however, it is not possible to accurately ascertain from the information it provides the date on which individual provisions of these policies were originally enacted. I have therefore omitted the 29 Kentucky policies from my sample. I note, however, that all 29 school districts represented had a peer sexual harassment policy in place by 2002 .

4. Arizona is in the Ninth Circuit, which did not hold schools liable for peer sexual harassment until 1998. No reported cases arose in Arizona. Georgia, on the other hand, is where the Davis case arose. While it may have been the site of much publicity about peer sexual harassment, the local district court and the full Eleventh Circuit made clear that schools could not be held legally liable for it. South Carolina, like Arizona, had no peer sexual harassment cases of its own. It is located in the Fourth Circuit, which initially found a university liable for peer sexual harassment in 1997 , in a case that was promptly vacated by the Fourth Circuit en banc and never reinstated. So South Carolina had no law on peer sexual harassment before Davis was decided. Despite their different legal environments, trends in each individual state are consistent with overall trends for the three. State law in these jurisdictions was silent on peer sexual harassment.

5. I interviewed: (1) Yolanda Wu, lead counsel on peer sexual harassment cases for the National Organization for Women's Legal Defense Fund (NOWLDF), which coordinated peer sexual harassment litigation around the country; (2) a former employee of the U.S. Department of Education; (3) Nan Stein, a prominent researcher, author and activist on peer sexual harassment; and (4) Administrators at Mitchell Middle School (not the school's real name), a public school in Queens, New York.

6. $A S B J$ reaches 40,000 school board members, superintendents, school business officials, principals, and other key administrators each month. Teacher Magazine claims a readership of 1.3 million educators and is delivered to the teacher's lounge in every public, private, and parochial school in the U.S. The Bulletin reaches each of the National Association of Secondary School Principal's 35,000 members. Unlike the others, it is a peer-reviewed, quarterly publication that serves as a long-term resource for its readers.

7. To locate the articles in Education Week and Teacher Magazine, I conducted term searches in archival databases using the terms "peer sexual harassment" and "student sexual harassment." I manually searched hard copies of back issues of $A S B J$ and The Bulletin, locating all articles that discussed the issue of students sexually harassing students, regardless what terminology was applied to this behavior.

8. In addition to the articles in my sample, there were some in the education trade publications I reviewed discussing whether harassment based on sexual orientation constitutes legally actionable sexual harassment. I omit these articles from 
my analysis because they represent a dialogue about a separate and as yet undecided legal issue, and they follow their own distinct timeline and trajectory. I note, however, that they appear to follow a parallel trajectory, with articles treating the harassment of lesbian, gay, bi-sexual and transgender students as illegal sexual harassment even though this issue is still being litigated.

9. By contrast, the Department of Education (DOE), the agency responsible for administering Title IX, did not provide any guidance on peer sexual harassment until 1996. The agency published a proposed rule in 1996 (Fed Reg 1996), and it was not until 1997, twenty-five years after passage of Title IX, that the DOE's sexual harassment regulations were finalized and distributed to school districts (Fed Reg 1997). Because DOE's peer harassment regulation arrived relatively late on the scene, it had little impact on the development of peer sexual harassment law in the courts. In fact, some courts explicitly declined to follow it, casting it as a cynical attempt to manipulate ongoing litigation rather than an accurate reflection of department policy.

10. While no national data exist on the absolute number of schools with such policies, these surveys suggest that a substantial majority of public schools not only adopted policies within a relatively short period of time, but publicized them broadly enough that students were aware of them. There are limitations inherent in the available data. Because it was students and not administrators that were questioned, one is forced to draw inferences about the absolute number of schools with policies. It could be that this survey over-reports the presence of sexual harassment policies if students reported their existence incorrectly. I believe, however, that the inference I have drawn is better supported by my research. Within the schools where I conducted interviews, individuals in the school community - even teachers and administrators - were much more likely to think that no policy existed when in fact one did than to mistakenly believe that there was one.

11. Interview 22 March 2002. Tapes and transcripts on file with the author.

12. Interview 22 March 2002. Tapes and transcripts on file with the author.

13. The table divides articles into relevant time periods and presents separate data on the subset of articles explicitly discussing liability for the two early time periods, in which not all articles addressed the issue of liability.

14. Interview 6 November 2001. Tapes and transcripts on file with the author.

15. Interview 9 November 2001. Tapes and transcripts on file with the author.

16. Interview 22 March 2002. Tapes and transcripts on file with the author.

17. Interview 9 November 2001. Tapes and transcripts on file with the author.

18. Interview 7 November 2001. Tapes and transcripts on file with the author.

19. Interview 7 November 2001. Tapes and transcripts on file with the author.

20. A rough statistical breakdown of pre- and post-Davis litigation confirms that this case was not the hole in the dam feared by the dissent. In January 2003, a LEXIS-NEXIS search produced thirty-five published federal district court opinions directly addressing the issue of peer sexual harassment. Of those, twentysix, or more than 74 percent, were decided before the Supreme Court handed down Davis. Five more were issued in 1999 or 2000 . Given the lengthy timetable for litigation, it is almost certain that these cases were filed before Davis was decided in 1999. The high-water mark for peer sexual harassment litigation occurred in 1997, with seven cases decided in that year alone. But the pace of decisions has been declining ever since. No new decisions came down in 2001, and only four have surfaced since then. Notably, all of them were resolved in favor of the school board, finding that plaintiffs had not proven peer sexual harassment sufficiently severe or pervasive to state a claim under the tough Davis standard.

21. Interview Nan Stein, 2002. 


\section{APPENDIX A: CODING KEY}

Liability: Coded yes if article discusses liability for peer sexual harassment, no if it does not.

LiabYes: This subset of articles that discuss liability are coded yes if article: (1) states peer sexual harassment is illegal or that school officials can be held liable for it under some legal theory; (2) quotes another source stating same; or (3) cites a court case holding a school district liable for peer sexual harassment. Coded no otherwise.

LiabNo: This subset of articles that discuss liability are coded yes if article states school districts are not or should not be liable for peer sexual harassment or cites a case where the school district was found not liable (including jury verdicts exonerating school districts prior to fixing of liability in Davis). Coded no otherwise.*

Ambig: Coded yes if either of two conditions is met: (1) article discusses cases that differ in outcome on the issue of liability; or (2) article uses linguistic hedges regarding liability, stating, for instance, that courts are "divided" or that the law is "not clear."

Anecdote: Coded yes if article contains anecdotal evidence of schools being sued or settling claims for peer sexual harassment. Distinct from "LiabYes" in that the legal basis or validity of these claims is not discussed.

Policy: Coded yes if article recommends that schools adopt a policy to deal with peer sexual harassment or if it cites examples of other schools that have adopted such policies.

17/HH: Coded yes if article mentions the Seventeen magazine survey or the Hostile Hallways survey conducted by the Association of American University Women.

Franklin: Coded yes if article mentions the U.S. Supreme Court case, Franklin v Gwinnett County Public Schools, which held that schools can be held liable for monetary damages under Title IX for harassment of students by school personnel.

Hill: Coded yes if article mentions the Anita Hill-Clarence Thomas Supreme Court confirmation hearings.

Moral: Coded yes if the article takes or reports a strong stance against peer sexual harassment on moral or pedagogical grounds.

* Note that this coding method produces some overlap between LiabYes and LiabNo variables because some articles report both possibilities.

\section{REFERENCES}

DiMaggio, Paul (1988) "Interest and Agency in Institutional Theory." In Institutional Patterns and Organizations: Culture and Environment, edited by L. G. Zucker. Cambridge, Mass: Ballinger Publishing Co.

Dobbin, Frank, and John R. Sutton (1998) "The Strength of a Weak State: The Rights Revolution and the Rise of Human Resources Management Divisions," American Journal of Sociology 104: 441-76.

Dowling-Sendor, Benjamin (1998) "When Teachers Harass Students," American School Board Journal 185(2): 16-17.

Dowling-Sendor, Benjamin (1999) "Beyond Teasing: Districts Could Be Liable For Student Sexual Harassment," American School Board Journal 186(8): 16-17.

Edelman, Lauren B. (1992) "Legal Ambiguity and Symbolic Structures: Organizational Mediation of Civil Rights Law," American Journal of Sociology 97: 1531-76. 
Edelman, Lauren B., Steven E. Abraham, and Howard S. Erlanger (1992) "Professional Construction of Law: The Inflated Threat of Wrongful Discharge," Law \& Society Review 26: 47-83.

Edelman, Lauren B., Howard S. Erlanger, and John Lande (1993) "Internal Dispute Resolution: The Transformation of Civil Rights in the Workplace," Law \& Society Review 27: 497-534.

Edelman, Lauren B., Chirstopher Uggen, and Howard S. Erlanger (1999) "The Endogeneity of Legal Regulation: Grievance Procedures as Rational Myth," American Journal of Sociology 105: 406-54.

Edelman, Lauren B., Sally Riggs Fuller, and Iona Mara-Drita (2001) "Diversity Rhetoric and the Managerialization of Law," American Journal of Sociology 106: 1589-1641.

Ewick, Patricia, and Susan S. Silbey. (1998) The Common Place of Law: Stories From Everyday Life. Chicago: Univ. of Chicago Press.

Garth, Bryant, and Austin Sarat (eds.) (1998) How Does Law Matter? Evanston, Ill: Northwestern Univ. Press.

Gould, Jon B. (2001) "The Precedent That Wasn't: College Hate Speech Codes and the Two Faces of Legal Compliance," Law \& Society Review 35: 345-92.

Larkin, June (1994) Sexual Harassment: High School Girls Speak Out. Toronto: Second Story Press.

Layman, Nancy S. (1994) Sexual Harassment in American Secondary Schools: A Legal Guide for Administrators, Teachers and Students. Dallas: Contemporary Research Press.

Lawton, Millicent (1993) "Sexual Harassment of Students Target of District Policies," Education Week 2 February. Available at http://www.edweek.org (accessed February 2002).

Lawton, Millicent (1996) "District May Be Held Liable for Harassment, Court Warns," Education Week 21 February: 5.

McAdam, Doug, John D. McCarthy, and Mayer N. Zald (1996) "Introduction: Opportunities, Mobilizing Structures, and Framing Processes-Toward A Synthetic, Comparative Perspective on Social Movements." In Comparative Perspectives on Social Movements: Political Opportunities, Mobilizing Structures, and Cultural Framings, edited by D. McAdam, J. D. McCarthy \& M. N. Zald. Cambridge: Cambridge Univ. Press.

McCann, Michael W. (1994) Rights at Work: Law and the Politics of Pay Equity. Chicago: Univ. of Chicago Press.

Meyer, John W., and Brian Rowan (1983) "Institutionalized Organizations: Formal Structure as Myth and Ceremony," American Journal of Sociology 83: 340-63.

National Education Association (1992) Sexual Harassment and Schools, videorecording, produced by The Learning Channel and the National Education Association.

National Middle Schools Association (1995) Sexual Harassment: It's Hurting People, videorecording, produced by Quality Work Environments and the National Middle School Association.

Sarat, Austin, and Jonathan Simon (2003) "Cultural Analysis, Cultural Studies, and the Situation of Legal Scholarship." In Cultural Analysis, Cultural Studies, and the Law, edited by A. Sarat \& J. Simon. Durham: Duke Univ. Press.

Sendor, Benjamin (1996a) "Girls Still Need Title IX Protection," American School Board Journal 183(9): 17-18.

Sendor, Benjamin (1996b) "Clear Signals on Two Thorny Issues," American School Board Journal 183(12): 18-19.

Shoop, Robert J., and Jack W. Hayhow, Jr. (1994) Sexual Harassment in our Schools. Boston: Allyn \& Bacon.

Stein, Nan (1991) "It Happens Here Too: Sexual Harassment in the Schools," Education Week 27 November: 32. 
Stein, Nan (1994) Flirting or Hurting? A Teacher's Guide on Student-to-Student Sexual Harassment in Schools (Grades 6 through 12). Washington, D.C.: NEA Professional Library.

Stein, Nan (1999) Classrooms and Courtrooms: Facing Sexual Harassment in K-12 Schools. New York: Teachers College Press.

Stein, Nan, Nancy L. Marshall, and Linda Tropp (1993) Secrets In Public: Sexual Harassment in Our Schools: A Report of the Results of a Seventeen Magazine Survey. New York: NOW Legal Defense and Education Fund.

Sutton, John R., Frank Dobbin, John W. Meyer, and Richard Scott (1994) "The Legalization of the Workplace," American Journal of Sociology 99: 94471.

Teacher Magazine (1993) "A National Disgrace," Teacher Magazine. Available online at http://www.edweek.org/tm/tm_printstory.cfm?slug=4stein.h04 (accessed 25 February 2002).

Walsh, Mark (1991) "Issue of Sexual Harassment in Schools Moves to Supreme Court," Education Week 11 December: 1, 15.

Walsh, Mark (1993) "Court Asked to Define Sex Harassment in the Workplace," Education Week October 20. Available at http://www.edweek.org (accessed 25 February 2002).

Walsh, Mark (1998) "Riley Restates Rules Against Harassment," Education Week 8 July: $1,30$.

Walsh, Mark (1999) "Damages Are Not Available for Simple Acts of Teasing." Education Week 2 June: 1, 22.

Zald, Mayer N. (1996) "Culture, Ideology, and Strategic Framing." In Comparative Perspectives on Social Movements: Political Opportunities, Mobilizing Structures, and Cultural Framings, edited by D. McAdam, J. D. McCarthy \& M. N. Zald. Cambridge: Cambridge Univ. Press.

\section{CASES CITED}

Bruneau v South Kortright Central Sch. Dist., 935 F Supp 162 (ND NY 1996).

Bruneau v South Kortright Central Sch. Dist., 163 F3d 749 (2d Cir 1998).

Burlington Industries v Ellerth, 524 US 742 (1998).

Clausing v San Francisco Unified Sch. Dist., 221 Cal App 3d 1224 (1990).

Davis v Monroe County Bd of Education, 862 F Supp 363 (MD Ga 1994), aff'd in part, rev'd in part, and rem'd by Davis v Monroe County Bd. of Education, 74 F3d 1186 (11 th Cir 1996); vacated by, reh'g en banc granted by Davis v Monroe County Bd. of Education, 91 F3d 1418 (11th Cir 1996); different results reached on reh'g en banc, Davis v Monroe County Bd of Education, 120 F3d 1390 (11th Cir 1997 en banc).

Davis v Monroe County Bd. of Education, 120 F3d 1390 (11th Cir 1997 en banc); revd by Davis v Monroe County Bd. of Education, 526 US 629 (1999).

Davis v Monroe County Bd. of Education, 526 US 629 (1999).

Doe v Petaluma City Sch. Dist., 830 F Supp 1560 (ND Cal 1993).

Faragher v City of Boca Raton, 524 US 775 (1998).

Fleming v Boeing Co., 120 F3d 242 (1 lth Cir 1997).

Franklin v Gwinnett County Public Schools, 503 US 60 (1992).

Harris v Forklift Systems, 510 US 17 (1993).

Kinman v Omaha Public Sch. Dist., 94 F3d 463 (8th Cir 1996).

Meritor Savings Bank, FSB v Vinson et al., 477 US 51 (1986).

Oona v McCaffrey, 143 F3d 473 (9th Cir 1998).

Perry v Ethan Allen, Inc, 115 F3d 143 (2d Cir 1997). 
Rowinsky v Bryan Independent Sch. Dist., 80 F3d 1006 (5th Cir 1996), questioned by Davis v Monroe County Bd of Education, 526 US 629 (1999).

United Stated v Lopez, 512 US 1286 (1994).

LAWS CITED

61 Fed Reg 42728 (1996).

62 Fed Reg 12039 (1997).

29 CFR §1604.11(a)(3) (2002).

Civil Rights Act of 1964 (Title VII), 42 USC $\$ 2000 \mathrm{e}-2$ et seq.

Education Amendments of 1972 (Title IX) , 20 USC $\$ 1681$ et seq. 